\title{
City Branding with Tourism: A systematic mapping study
}

\author{
Asep Miftahuddin ${ }^{1}$, Bambang Hermanto ${ }^{2}$, Sam'un Jaja Raharja ${ }^{3}$, Arianis Chan ${ }^{4}$, Dian \\ fordian $^{5}$ \\ Faculty of Social and Political Science, Department of Business Administration, Universitas \\ Padjadjaran $1,2,3,4,5$ \\ \{asep17012@mail.unpad.ac.id ${ }^{1}$,b.hermanto@unpad.ac.id², s.raharja2016@unpad.ac.id ${ }^{3}$, \\ arianis.chan@unpad.ac.id ${ }^{4}$,d.fordian@unpadac.id $\left.{ }^{5}\right\}$
}

\begin{abstract}
City branding a popular research theme from the database of the international journal such as Scopus so that it used as the main reference for researchers. The aim of the city branding research is to find empty gaps such as research methods, analytical techniques, and research sites. The method used is Systematic Mapping Studies (SMS ). The results showed that (1) research methods that are rarely used mix method (2) paper type that is rarely experienced paper research (3) Asia is rarely studied.
\end{abstract}

Keywords: city branding, tourism, systematic mapping study.

\section{Introduction}

Researching City Branding will make researcher possible to explore developing concepts of place to increase their economical values because the place branding model usually begins with place marketing method [1]. Nowadays, place marketing method is considered as an academic approach that is newly found and has an opportunity to become a challenging study in the future. The approach is designed to create ideas and concept that will give references needed by tourists if they decided to visit a certain tour destination and furthermore design their behavior in determining the tour destination. Place Marketing study can also involve various places with different levels [2]. In practice, Place marketing can also be applied in different districts environment, tourist destinations, cities, rural areas, region, and country. Metamorphically, the concept itself is a development of city marketing, destination marketing, national marketing and location branding [3].

Branding researches always attract researchers to research this field [4], [5] because place branding popularity needs a specific approach to discover the proper and more critical concept[6], [7]. The basic concept requires very special treatment to establish place branding with a proper and complex conceptualization and managerial method.

Success in managing place branding will attract tourists --domestic or foreign--, investors, and potential people [8] so that it can increase the economic growth within the 
surrounding place. Therefore, many recent kinds of literature suggest that stakeholders should implement their roles in determining the success or failure of the place branding concept [9], [10].

Place branding can be applied in various places with different characterization. There are several types of research using a developed Place Brand Experience methods [11]-[13] and those researches were used to develop a certain city's economical growth. These models were implemented as a concept to establish a creative city [14], and it is well-known as a new concept that similar to the concept of creative economy and creative industry.

To achieve research objectives, more research questions are required to find relevant and accurate findings on the electronic database all over the world. Overall, the researchers analyze the relevant search results with a study of city branding based on the formulation of main questions, which include:

1. RQ1: How is the focus and research locus on the topic being studied?

2. RQ2: How are the types of articles and research methods being used?

3. RQ3: How are the topics developed in each country from time to time?

\section{Methodology}

This study uses a systematic mapping study (SMS) which is a secondary study. SMS is rooted in the study literature review (SLR) introduced in the research of information technology [15]. Research with the SLR approach aims at identifying, evaluating, and interpreting all available and relevant literature sources, related to the research questions that have been formulated [16].

The most common reasons for performing SLRs are: First, to summarize the existing evidence on the topic; Second, to identify gaps in current research and to provide advice for future investigations; and Third, to give a background positioning new research activities [15].

\section{Searching Steps}

To increase the accuracy of the SMS study, the process of search and analysis should be done as accurately as possible. Thus, in this section characterizes the process of selecting the data source, the implementation strategy to generate search strings and determination of the exclusion and inclusion criteria.

This study adopted the searching process from [17] and [16]. In this process, each step which has results and systematic mapping becomes the result of the mapping process. In Figure 1, we illustrate the complete process of SMS used in this study, by referring to the research conducted and as instructed by [18] and [17].

The researchers conducted an online search on indexed electronic databases of the Scopus. Scopus is a library database containing abstracts and reputable international academic journals included in the criteria of the Directorate General of Higher Education (DIKTI) of the Republic of Indonesia. 


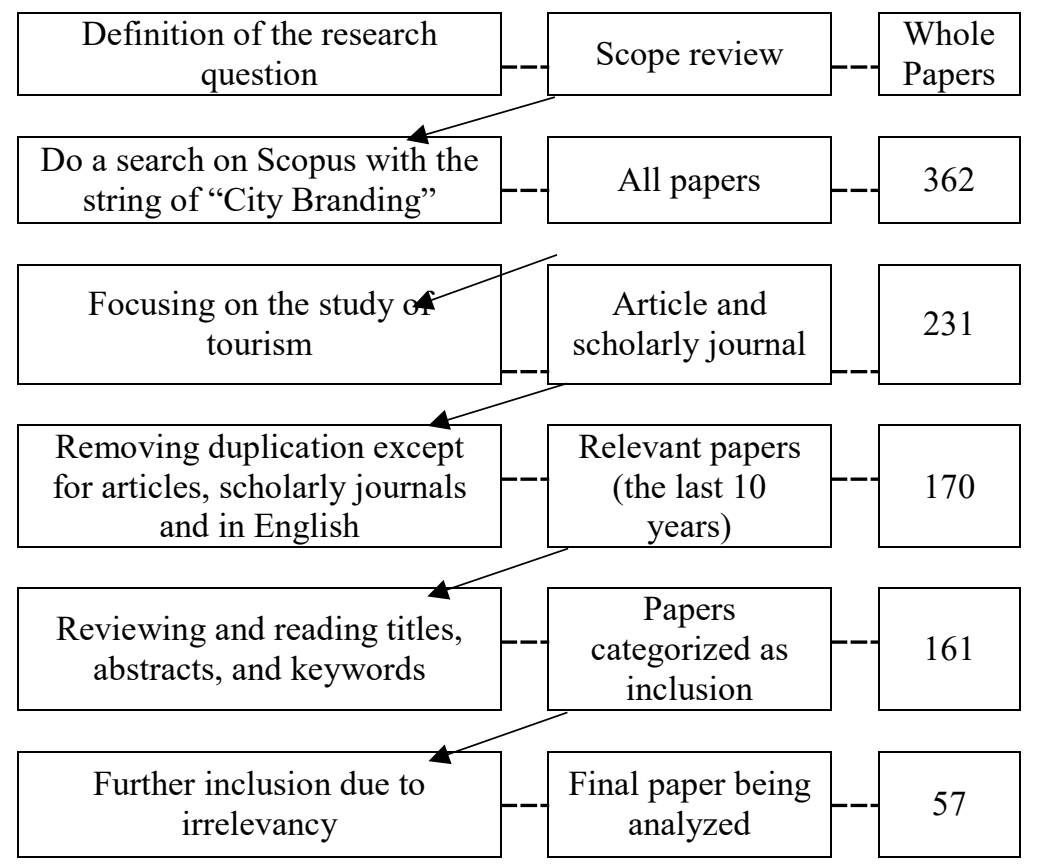

Figure 1. SMS Process (Searching)

Search strings or search keywords are created using strategies from [16] concerning the research of [19]. The first step is to define the main keyword. The second step is to examine the well-known research in the field of city branding. The third is to search for the alternative of keyword forms to be used in the search process.

The last step is to use Boolean operator whose function is to synthesize into one search string, but this research does not use the Boolean operator $A N D$ or $O R$ because in the third stage the researcher finds that if the string combination is "city branding" AND tourism, the researchers found 231 results.

However, if the search string simply does not use Boolean, the results found with the "city branding" string are 362 results. The search string above applies to searches on all parts of the articles, such as titles, abstracts, and keyword in Scopus electronic database. The search process began on December 25, 2018.

The further step to determine the category of exclusion articles called exclusion criteria and includes articles which is one of the mapping study activities to exclude irrelevant articles and include relevant articles. In this study, we formulated the exclusion and inclusion criteria to facilitate mapping.

\section{Result and Discussion}

\subsection{Research Results}

This section is the result of a mapping based on the research questions. Based on the mapping results of 231 articles on city branding and tourism grouped by using Microsoft Excel 
2013 applications with the category of research focus, research locus, methods, paper type, and the development of research in the world published by the Scopus. After doing the mapping systematically, it is found that 15 types of article documents originated from Indonesia.

\subsection{Focus and Research License (RQ1)}

To answer RQ1, we classify 210 articles on research focus areas with categories of City branding, City brand equity, Review brand, Place branding, Brand personality, etc.

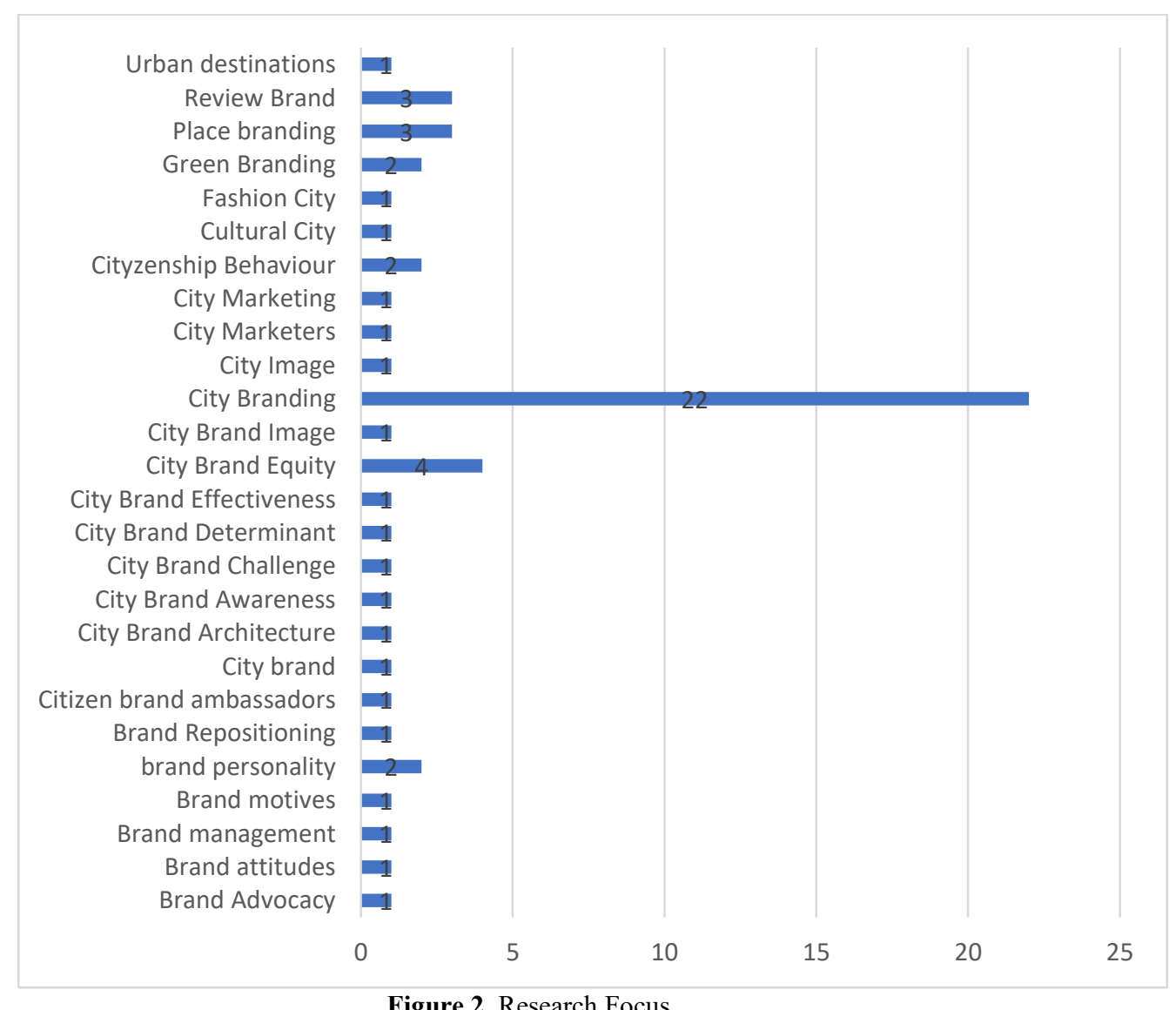

Figure 2. Research Focus

Figure 2 is the percentage of the topics being studied, most of which is the research with the focus on city branding 22 (36.60\%), City Brand Equity of 4 (7,02\%), Review Brand of 3 $59(16 \%)$, etc.

In the study of city branding, most researches study the city 43 studies, both in a database journal 3 studies, and word games in Kaohsiung, urban governance, university town, theme park, social media, rural landscape, public park, nation, Green city, danish place, architecture cultural each one studies. The researchers conclude that there are several studies that use the type of philosophical articles. (Figure 3). 


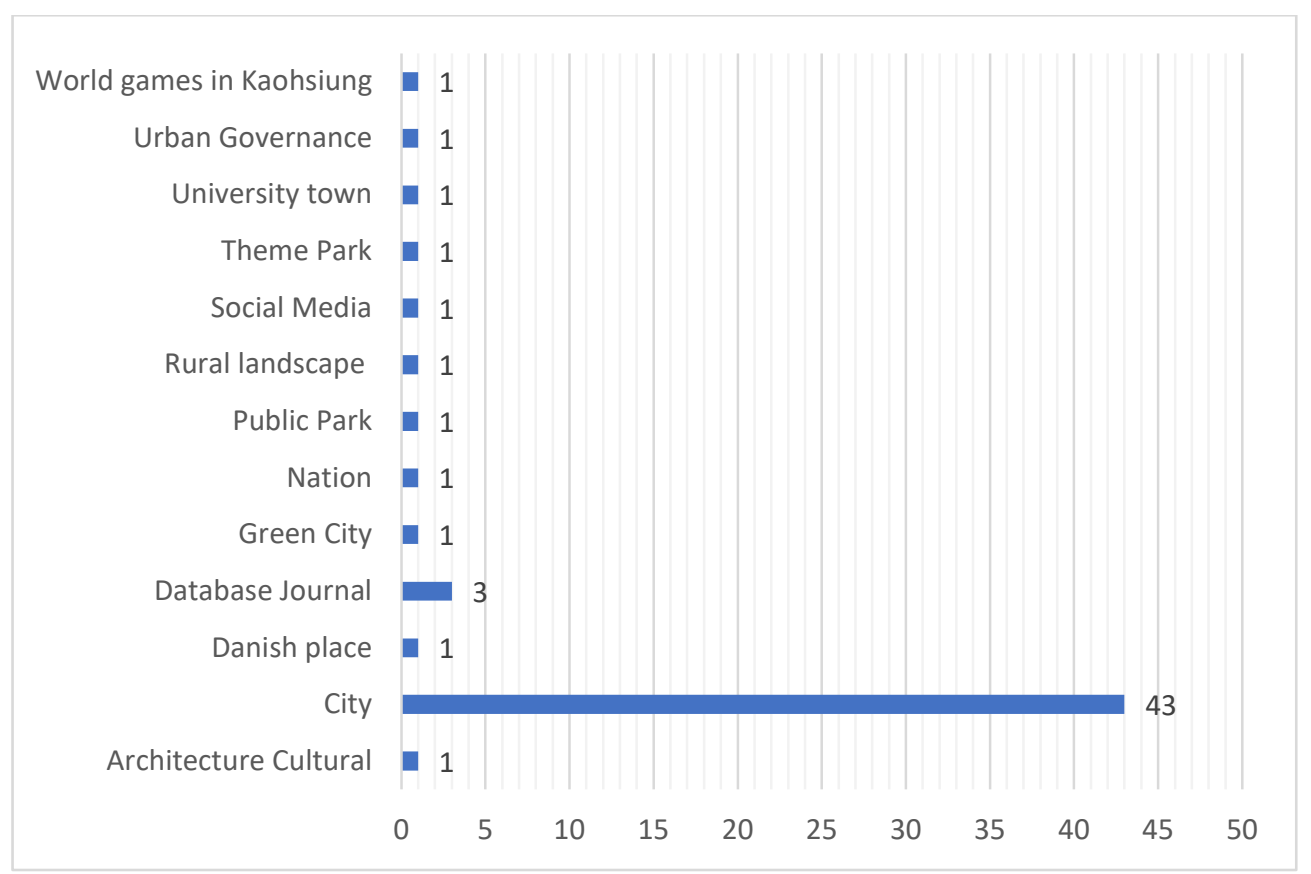

Figure 3. Research Locus

\subsection{Type of Article and Research Method (RQ2)}

Type of research article shows the classification of research that refers to the research of Wieringa et al. (2006), where the study is grouped into four categories: validation research; evaluation research; solution proposal; philosophical papers. To provide an answer for RQ2, we categorize 57 result studies of the classification mapping.

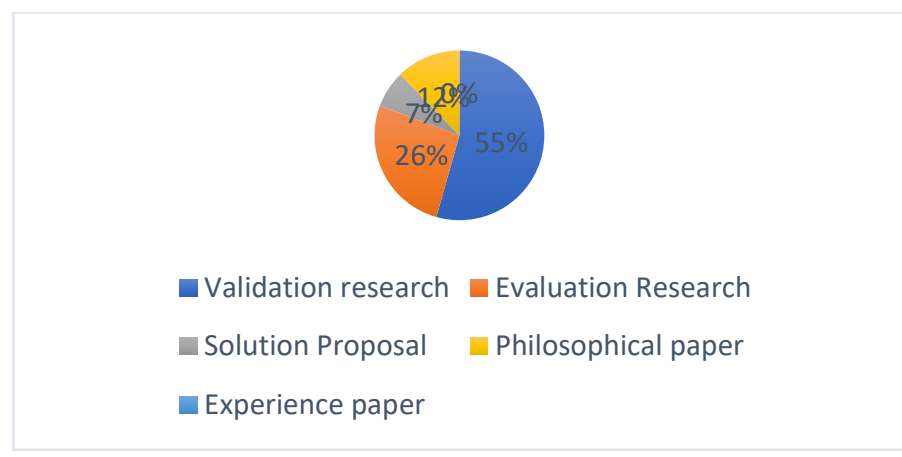

Figure 4. Article Type

Figure 4 illustrates the distribution of the article type (paper type) based on the classification category according to Wieringa et al. (2005). Based on the systematic mapping study, the most commonly used article type is validation research with a total of $31(55 \%)$ studies. The next most frequent article type is an evaluation type article with a total of 15 
$(26 \%)$ studies. The next is philosophical papers of 7 (12\%), a solution type article of $4(7 \%)$, and the least is experienced of $0(0 \%)$ studies.

The classification of research methods refers to the research of [21]. The research method used in this systematic mapping is the quantitative, qualitative and mixed-method approach. The accumulation of total findings of 57 Scopus-reputed journals is illustrated in figure 5.

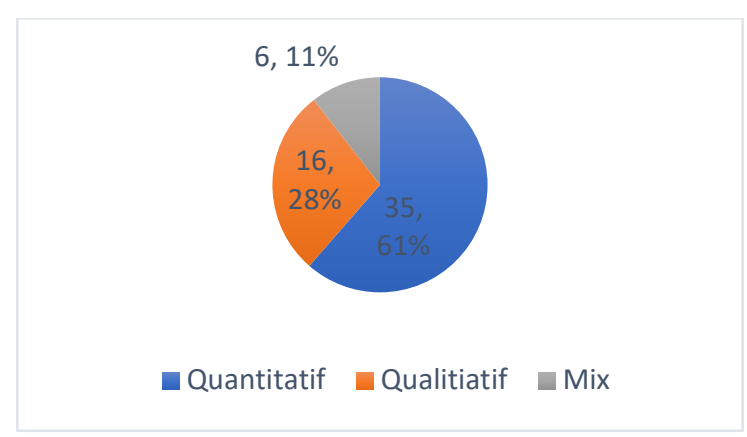

Figure 5. Research Method

The research approach using quantitative method is the most common method because its nature is to test and to evaluate. The total of articles of the research using quantitative approach is $35(35,61 \%)$ studies. The next is the article using a qualitative method comprising $16(16,28 \%)$ studies. And mixed-methods comprising $6(6.11 \%)$ studies.

\subsection{The trend of publication in each country from time to time (RQ3)}

Based on the results of the mapping, it is found that most countries produce research on city branding is Hongkong with a total of six publications, the USA with five publications. Polandia and Europe 4 publication, Korea, China, Australia with three publication, Turkey, Indonesia, Denmark, the Netherlands with two publication, etc. The description of the research trends of city branding is illustrated in Figure 6. 


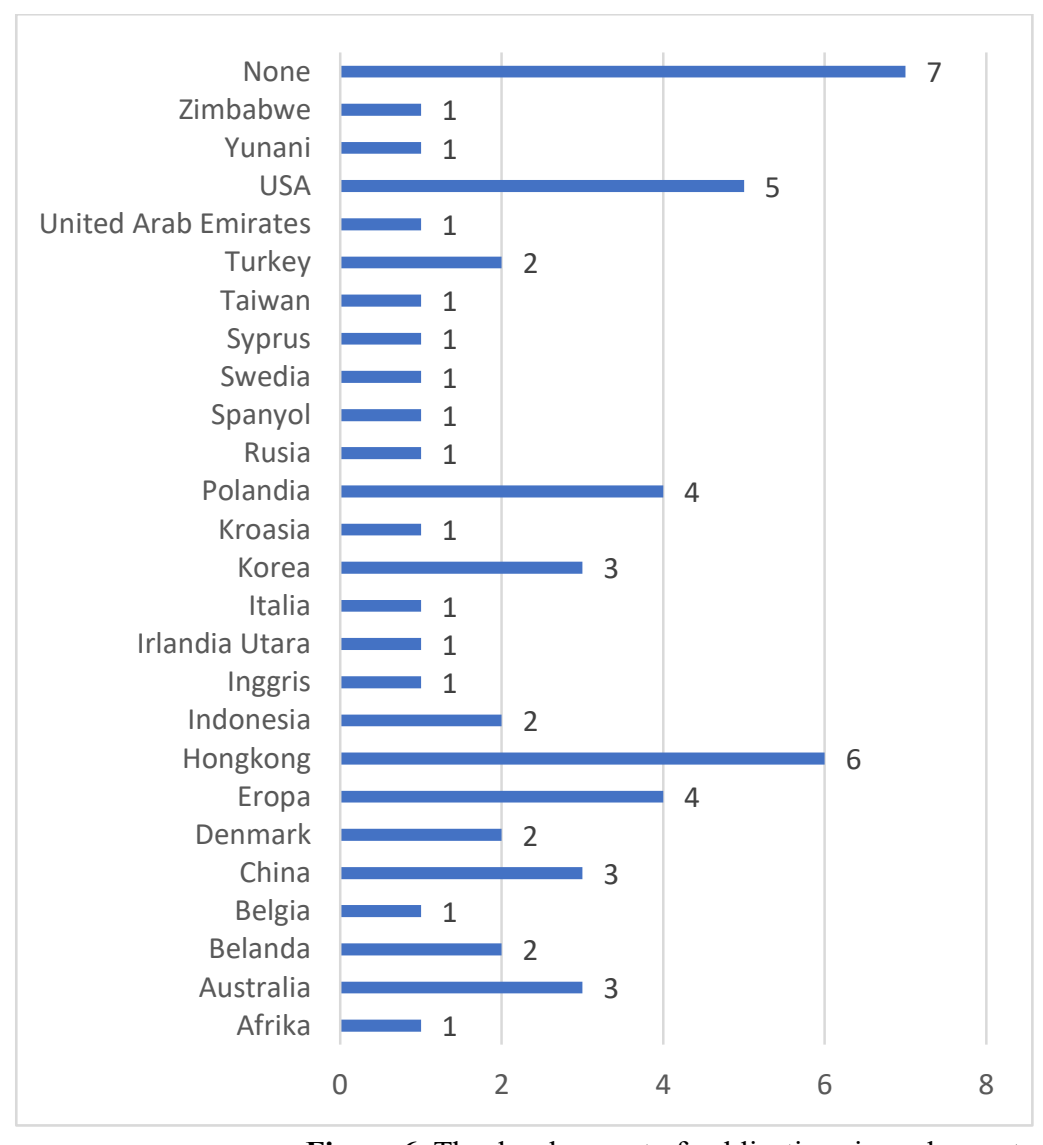

Figure 6. The development of publications in each country

Then, Figure 7 is the research trend published in electronic media database in the last 10 (ten) years that began in 2008 .

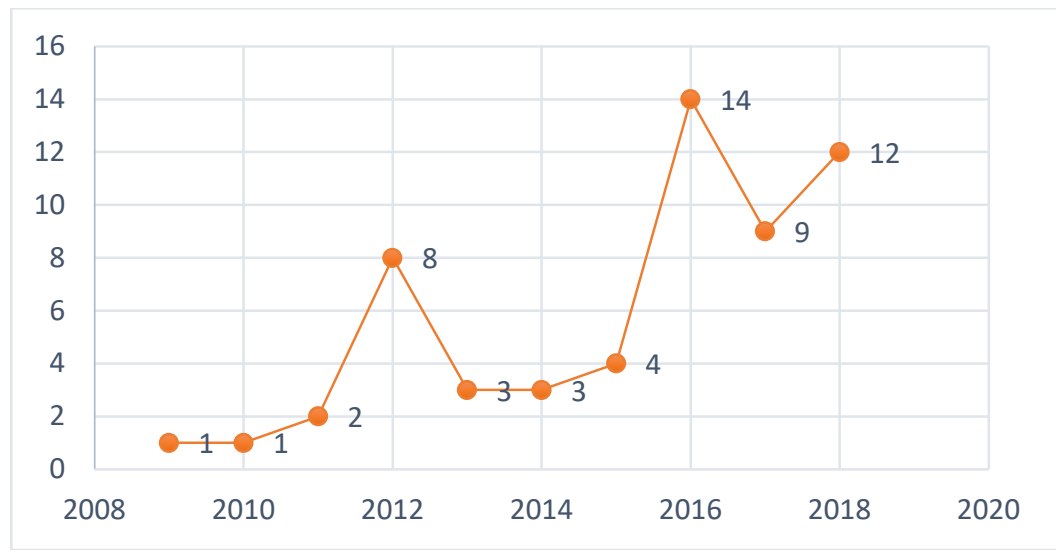

Figure 7. The development of publications from year to year 


\section{Summary, discussion, and implications}

There are millions of visitor who will come to the city. The impact is the growth of the economy rooted in business endurance. The academics, practitioners, research institutions and governments have a role in producing studies related to the city branding of tourism. The linkage between the academics, practitioners, research institutions and government with business actors, companies, industries, and business actors is to develop the concepts, and ideas about city branding.

This research mapped out the literature of city branding available on the Scopus scientific databases. The main motivation of the study being mapped is to provide an overview of the existing literature on the city branding as a solution to winning a business competition tourism sector.

The researchers apply the method of systematic mapping to determine what focus has been studied in the area of this research. Out of 57 research articles that have been mapped out systematically, we conclude that:

1) The topics widely studied are the study with the focus on city branding $22(36.60 \%)$, City Brand Equity of 4 (7,02\%), Review Brand of 359 (16\%).

2) The most commonly used type of article is validation research with a total of $31(55 \%)$ studies. The next most frequent article type is an evaluation type article with a total of $15(26 \%)$ studies. The next is philosophical papers of $7(12 \%)$, a solution type article of $4(7 \%)$, and the least is experienced of $0(0 \%)$ studies.

3) The country producing the most study on city branding is the is Hongkong with a total of six publications, the USA with five publications. Polandia and Europe 4 publication, Korea, China, Australia with three publication, Turkey, Indonesia, Denmark, the Netherlands with two publication, etc.

The research method adopted by SMS is a practical research method to identify the appropriate topics to be studied, as well as which areas are needed for more research. The result of this study provides guidance to assist researchers in planning future research through the discovery of research gaps.

\section{References}

[1] I. Aranburu, B. Plaza, and M. Esteban, "Sustainable cultural tourism in urban destinations: Does space matter?," Sustain., vol. 8, no. 8, 2016.

[2] G. Ashworth and H. Voogd, Selling the city : marketing approaches in public sector urban planning. 1990.

[3] E. Braun, "Putting city branding into practice," J. Brand Manag., vol. 19, no. 4, pp. 257-267, 2012.

[4] M. Hereźniak, M. Florek, and A. Augustyn, "On Measuring Place Brand Effectiveness-Between Theoretical Developments and Empirical Findings," Econ. Sociol., vol. 11, no. 2, pp. 36-52, 2018. 
[5] S. Zenker and S. C. Beckmann, "Measuring brand image effects of flagship projects for place brands: The case of Hamburg," J. Brand Manag., vol. 20, no. 8, pp. 642655, 2013.

[6] O. Kolotouchkina and G. Seisdedos, "The urban cultural appeal matrix: Identifying key elements of the cultural city brand profile using the example of Madrid," Place Brand. Public Dipl., vol. 12, no. 1, pp. 59-67, 2016.

[7] K. Peighambari, S. Sattari, T. Foster, and Å. Wallström, "Two tales of one city: Image versus identity,” Place Brand. Public Dipl., vol. 12, no. 4, pp. 314-328, 2016.

[8] K. C. Hudak, "Dahntahn discourses and neighborhood narratives: Communicating the city brand of Pittsburgh, Pennsylvania," Place Brand. Public Dipl., vol. 11, no. 1, pp. 34-50, 2015.

[9] L. Ye and E. Björner, "Linking city branding to multi-level urban governance in Chinese mega-cities: A case study of Guangzhou," Cities, vol. 80, pp. 29-37, 2018.

[10] C. S. Chan, "Health-related elements in green space branding in Hong Kong," Urban For. Urban Green., vol. 21, pp. 192-202, 2017.

[11] A. Acharya and Z. Rahman, "Place branding research: a thematic review and future research agenda," Int. Rev. Public Nonprofit Mark., vol. 13, no. 3, pp. 289-317, 2016.

[12] S. J. Barnes, J. Mattsson, and F. Sørensen, "Destination brand experience and visitor behavior: Testing a scale in the tourism context," Ann. Tour. Res., vol. 48, pp. 121139, 2014.

[13] J. J. Brakus, B. H. Schmitt, and L. Zarantonello, "Brand Experience: What Is It? How Is It Measured? Does It Affect Loyalty?,” J. Mark., vol. 73, no. 3, pp. 52-68, 2009.

[14] S. Oguztimur and U. Akturan, "Synthesis of City Branding Literature (1988-2014) as a Research Domain,” Int. J. Tour. Res., vol. 18, no. 4, pp. 357-372, 2016.

[15] B. Kitchenham and S. Charters, "Guidelines for performing Systematic Literature Reviews in Software Engineering," Engineering, vol. 2, p. 1051, 2007.

[16] N. Banaeianjahromi and K. Smolander, Understanding Obstacles in Enterprise Architecture Development. 2016.

[17] K. Petersen, R. Feldt, S. Mujtaba, and M. Mattsson, "Systematic mapping studies in software engineering," EASE'08 Proc. 12th Int. Conf. Eval. Assess. Softw. Eng., pp. 68-77, 2008.

[18] B. Kitchenham, "Procedures for performing systematic reviews," Keele, UK, Keele Univ., vol. 33, no. TR/SE-0401, p. 28, 2004.

[19] O. Barbosa and C. Alves, "A Systematic Mapping Study on Software Ecosystems," Proc. Work. Softw. Ecosyst. 2011, 2011.

[20] R. Wieringa, N. Maiden, N. Mead, and C. Rolland, "Requirements engineering paper classification and evaluation criteria: A proposal and a discussion," Requir. Eng., vol. 11, no. 1, pp. 102-107, 2006.

[21] L. S. Musianto, "Perbedaan pendekatan kuantitatif dengan pendekatan kualitatif dalam metode penelitian," J. Manag. dan Kewirausahaan, 2002. 
